\title{
Influence of heating on chemical composition, antioxidant activity and protein quality of an advanced line Amaranthus cruentus $L$. seed flour
}

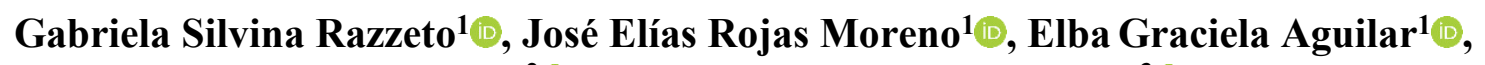
Edmundo Guillermo Peiretti² ${ }^{\oplus}$, Viviana Romina Lucero López ${ }^{3}$, Graciela de Jesús Albarracín ${ }^{1}$, Nora Lilian Escudero ${ }^{1}$ (D)

Cite this article as:

Razzeto, G.S., Rojas Moreno, J.E., Aguilar, E.G., Peiretti, E.G., Lucero López, V.R., Albarracín G. de J., Escudero, N.L. (2020). Influence of heating on chemical composition, antioxidant activity and protein quality of an advanced line Amaranthus cruentus L. Seed flour. Food and Health, 6(2), 67-76. https://doi.org/10.3153/FH20008

${ }^{1}$ Faculty of Chemistry, Biochemistry and Pharmacy, National University of San Luis, San Luis, Argentina

${ }^{2}$ Faculty of Agronomy and Veterinary, National University of Río Cuarto, Río Cuarto, Córdoba, Argentina

${ }^{3}$ School of Health, National University of Villa Mercedes, Villa Mercedes, San Luis, Argentina

ORCID IDs of the authors: G.S.R. 0000-0003-1268-3956 J.E.R.M. 0000-0002-7674-8264 E.G.A. 0000-0003-2856-6017 E.G.P. 0000-0001-7500-1583 V.R.L.L. 0000-0003-0863-8474 G.J.A. 0000-0003-3989-0111 N.L.E. 0000-0003-4378-5234

Submitted: 16.09 .2019

Revision requested: 24.10 .2019

Last revision received: 10.11 .2019

Accepted: 17.11.2019

Published online: 04.01.2020

Correspondence:

Viviana Romina LUCERO LÓPEZ

E-mail: vrominall@gmail.com

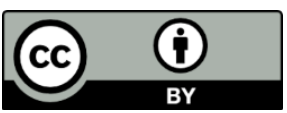

(C) Copyright 2020 by ScientificWebJournals Available online at

http://jfhs.scientificwebjournals.com

\begin{abstract}
Amaranth is a pseudocereal of Andean origin, and compared to other crops, its seeds have a higher content of proteins, lipids and bioactive compounds of nutraceutical relevance.

The goal of the present work is to study the chemical composition, antioxidant activity and biological value of the protein of an advance line Amaranthus cruentus L. seed flour (ACRU), compared with the same flour subjected to thermal treatment $\left(90^{\circ} \mathrm{C}, 1 \mathrm{~h}\right)$. Regarding the proximal chemical composition, the protein and lipid contents stand out, reaching values of $19.59 \mathrm{~g} \%$ and $7.47 \mathrm{~g} \%$, reflecting an increase of $17 \%$ and $50 \%$ in the treated sample, respectively. A significant increase $(\mathrm{p}<0.05)$ is observed in the ash content, as well as in the content of the main elements of nutritional interest, of the treated samples. The anti-nutrients values are within the acceptable limits in all samples, and present an adequate content of total phenols, with an antioxidant activity highlighted by its free-radical scavenging capacity. In the biological tests, the Net Protein Utilization (NPU) presents lower values for the treated samples, the True Digestibility (tD) does not show significant differences, and the Biological Value (BV) turns out to be lower in the treated sample $(\mathrm{p}<0.05)$. A significant hypotriglyceridemic effect is observed. The applied thermal treatment, even though increases the nutrients concentration and the total phenols, according to the biological tests, it decreases the protein quality. These are aspects that should be contemplated in the food technology to optimize the nutritional quality of this amaranth.
\end{abstract}

Keywords: Amaranth, Antioxidant capacity, Biological value, Chemical composition, Thermal treatment 


\section{Introduction}

Amaranth is an indigenous plant from America that has been used for more than 4000 years. In the last decades, it has regained popularity due to beneficial nutritional aspects, its agronomic advantages, such as its wide adaptability, and the possibility of its use as horticultural, graniferous and fodder, as well as for being one of the most promising resources to contribute towards mitigating food deficit (Dodok, 1997).

The amaranth nutritional composition is distinguished by the protein and lipid contribution. The protein content is between 12 to $22 \%$ (Tosi et al. 2001; Escudero et al. 2004; Barba de la Rosa et al. 2009). The proteins quality depends on the composition of essential amino acids and digestibility. Protein digestibility, lysine availability and net protein utilization of the amaranth proteins are higher than of cereals, and similar to those of casein (Salcedo-Chávez et al. 2002). The constituent amino acids of food proteins are not always fully available, due to that the protein digestibility and amino acid adsorption can be incomplete. Thus, the thermal treatment and milling applied to the seeds for the production of flour can raise the foods nutritional quality by the denaturalization of its proteins and the digestibility increase (Giami et al. 2001; Sun et al. 2014).

In order to expand the biodiversity and increase the agronomical efficiency of crops in the Central - West region of Argentina, new improved varieties have been obtained, such as the Acru-G10/13II, the advanced line belonging to the Amaranthus cruentus L. species. The latter is characterized for expressing good yields and excellent adaptation; it presents dark green foliage, semi-compact to compact dark red panicle, and a height between 1.40 and $1.70 \mathrm{~m}$. It has a total cycle of 115 days and an acceptable behavior against "stem borer" (Conotrachelus spp.). The goal of this study is to evaluate the effect of thermal treatment on the chemical composition, antioxidant activity and biological quality of a new amaranth variety seed flour.

\section{Materials and Methods}

\section{Sample}

Seeds of a new variety of Amaranthus (Acru-G10/13 II) were supplied by the Faculty of Agronomy and Veterinary, National University of Río Cuarto, Cordoba, Argentina (experimental crop from 2016 vintage).

\section{Sample Treatment}

Dried seeds were ground in a grain mill and sieved through a $200 \mu \mathrm{m}$ diameter mesh. A flour portion was used untreated (ACRU) and another was exposed to $90^{\circ} \mathrm{C}$ for 1 hour in an air-current oven (Dalvo HER/F/I, Argentina) (ACRU treated). The flours obtained were kept in closed containers protected from light, in a cool and dry environment until analysis.

\section{Reagents}

All reagents used were of analytical grade and acquired from Sigma (St. Louis, MO). All standard solutions were prepared using reagents of spectroscopic grade supplied by Merck (Darmstadt, Germany). Ultrapure water $(18.2 \mathrm{M} \Omega \mathrm{cm})$ was used to prepare all standard and sample solutions.

\section{Chemical Composition}

The determination of moisture, ash, protein, total lipids and crude fiber was performed according to the methodology proposed by the AOAC (2012). Carbohydrates are determined by the following calculation:

Carbohydrates $=100-(\%$ Ash $)-(\%$ Total Fat $)-(\%$ Moisture $)$ - (\% Protein $)$

The quantification of mineral elements was performed by Inductively Coupled Plasma Atomic Emission Spectroscopy (ICP-OES). The procedure was performed following the methodology used by Aguilar et al. (2011).

The antinutrients determined were: nitrates (Cataldo et al. 1975), hemagglutinin activity (lectins) (Das Gupta and Boroff 1968; Do Prado et al. 1980), saponins (WHO/PHARM/92559 1992; Duarte Correa and Carlsson, 1986), antitrypsin activity (Kakade et al. 1974), oxalic acid (AOAC 1995) and phytic acid (Rucci and Bertoni, 1974).

The extraction of total phenols was performed from a defatted sample with $1.2 \mathrm{M} \mathrm{HCl}$ in $50 \%$ methanol/water. The sample was heated at $90{ }^{\circ} \mathrm{C}$ for $3 \mathrm{~h}$, cooled, and then diluted with methanol. The supernatant was used for the determination of total phenols and antioxidant activity (Vinson et al. 2001). The concentration of the obtained extract was $5 \mathrm{mg} / \mathrm{mL}$. The determination of total phenols was performed using Folin Ciocalteu reagent with gallic acid as a standard. The absorbance was measured at $750 \mathrm{~nm}\left(\mathrm{UV}-\right.$ vis BeckmanDK-2 $\left.{ }^{\mathrm{a}}\right)$. Results were expressed as $\mathrm{mg} / 100 \mathrm{~g}$ of dry weight of gallic acid equivalent (Emmons et al. 2001).

\section{Antioxidant Activity}

DPPH Free Radical-Scavenging Assay. This spectrophotometric assay uses the stable radical DPPH (1,1-diphenyl-2picrylhydrazyl) as a reagent (Burits and Bucar, 2000). Various concentrations of the extract in methanol were added to a $40 \mathrm{mg} / \mathrm{L}$ methanol solution of DPPH. The absorbance was read at $517 \mathrm{~nm}$ (UV-Vis Beckman DK-2a). Results were expressed as percentage (\%) of radical scavenging activity (RSA). 
Scavenging Activity against Nitric Oxide (NO Test). Nitric oxide (NO) was generated from sodium nitroprusside and measured by Griess reaction (Marcocci et al. 1994; Saija et al. 1999). Nitrite concentration was calculated by referring to the absorbance of standard solutions of sodium nitrite. Absorbance was measured in a spectrophotometer (UV-Vis Beckman DK-2a) at $542 \mathrm{~nm}$. Results were expressed as percentage (\%) of RSA with respect to blank.

\section{B-Carotene-Linoleic Acid Assay}

This assay involves measuring $\beta$-carotene bleaching, at 470 $\mathrm{nm}$, resulting from the $\beta$-carotene oxidation by linoleic acid degradation products at $50^{\circ} \mathrm{C}$ (Koleva et al., 2002). The absorbance at $470 \mathrm{~nm}$ was taken at time zero $(t=0)$, and measured every $15 \mathrm{~min}$ until the color of $\beta$-carotene disappeared in the control tubes $(t=60 \mathrm{~min})$. A mixture prepared as above but without $\beta$-carotene served as blank. BHT (butylated hydroxytoluene) was included in the experiments as a positive control. Results were expressed as percentage (\%) of RSA.

All determinations above were performed in triplicate.

\section{Biological Assay}

The Pprotein quality of the amaranths flour was measured by three different indices: Net Protein Utilization (NPU), true digestibility (tD), and Biological Value (BV) (Miller and Bender, 1955; Pellet and Young, 1980). Four groups of 30day-old Wistar rats weighing 30-40 g ( \pm 2 g weight difference) were used (six animals per group). One group received a protein-free diet, another received a control diet (casein), and the remaining groups received a diet with protein provided by the material under study. The preparation and composition of the diets were carried out according to AIN 93G (Table 1) and the NPU method at $10 \%$ of proteins and $7 \%$ of lipids (Reeves et al. 1993). The amount of flour incorporated in the diets to achieve $10 \%$ of protein, was defined taking into account the protein content of the sources, ACRU: 19.59 $\%$ and ACRU treated: $23.54 \%$. Casein: $80 \%$ purity. The amount of oil added to achieve $7 \%$ of lipids, was defined taking into account the fat content obtained for the sources, ACRU: $7.47 \%$ and ACRU treated: $14.70 \%$.

The animals were kept in individual suspended cages with screen bottoms. Temperature and relative humidity were held at $21 \pm 1{ }^{\circ} \mathrm{C}$ and $60 \%$, respectively. Lighting was controlled by alternating 12-h periods of light and darkness. All animals received potable water and food ad libitum for 14 days. Ingestion was recorded on days 3, 6, and 10; weight gain was recorded at the end of the experiment. Feces were collected and weighed. After the experiment, the euthanasia of the animals was performed through a carbon dioxide chamber. Subsequently, a thoracic and abdominal incision was performed, and the rats were weighed and placed in a forced air oven at $100-105^{\circ} \mathrm{C}$ for 48 hours to determine the body water by weight difference. We followed the general guidelines for the care and use of laboratory animals recommended by the Animal Care Committee of the National University of San Luis.

The NPU is defined as the portion of nitrogen intake that is retained. The formula used was

$\mathrm{NPU}=\frac{B-(B \mathrm{~K}-I \mathrm{~K})}{I} \times 100$

where $B$ is the corporal nitrogen of the experimental group; $B \mathrm{~K}$ is the corporal nitrogen of the group on the protein-free diet; $I \mathrm{~K}$ is the nitrogen intake of the group on the protein-free diet; and $I$ is the nitrogen intake in the experimental group. Corporal nitrogen $(N)$ was calculated by using the following equation:

$Y=2.92+0.02 X$

where $X$ is the rats age in days, and $Y$ is calculated as

$Y=\frac{\mathrm{N}(\mathrm{g}) \times 100}{\mathrm{H}_{2} \mathrm{O}(\mathrm{g})}(2)$

By equating Eqs. (1) and (2), $\mathrm{N}$ is calculated as

$\mathrm{N}(\mathrm{g})=\underline{\mathrm{H}_{2} \mathrm{O}(2.92+0.02 X)}$

100

tD was determined along with NPU, and was considered as the absorbed nitrogen with respect to the $\mathrm{N}$ intake. Unabsorbed nitrogen was calculated by quantification of the fecal nitrogen in the group fed with the protein-free diet. The formula used was

$\mathrm{tD}=\frac{I-(F-F K)}{I} \times 100$

where $I$ is the ingested nitrogen; $F$ is the fecal nitrogen in the group that received the experimental diet; and $F K$ is the fecal nitrogen of the group consuming the protein-free diet.

The biological value (BV) was calculated as the NPU/tD ratio. 
Table 1. Composition of diets AIN 93-G

\begin{tabular}{lcccc}
\hline Nutrients (g/kg) & Protein free & Casein & ACRU & ACRU Treated \\
\hline Cornstarch & 397.48 & 397.48 & 85.16 & 164.16 \\
Protein $^{\text {a }}$ & 0 & 125.00 & 510.50 & 424.71 \\
Soybean oil $^{\text {b }}$ & 70.00 & 70.00 & 31.86 & 7.56 \\
Fiber & 50.00 & 50.00 & 20.08 & 29.23 \\
Sucrose & 100.00 & 100.00 & 100.00 & 100.00 \\
Mineral mix & 35.00 & 35.00 & 35.00 & 35.00 \\
Vitamin mix & 10.00 & 10.00 & 10.00 & 10.00 \\
Choline bitartrate & 2.50 & 2.50 & 2.50 & 2.50 \\
L-Cystine & 0 & 3.00 & 0 & 0 \\
Dextrinized cornstarch & 335.00 & 207.00 & 284.87 & 226.80 \\
Tert-butylhydroquinone & 0.014 & 0.014 & 0.014 & 0.014
\end{tabular}

${ }^{\mathrm{a}}$ The amount of flour incorporated in the diets to achieve $10 \%$ of protein was defined taking into account the protein content of the sources, ACRU: $19.59 \%$ and ACRU treated: $23.54 \%$. Casein: $80 \%$ purity.

b The amount of oil added to achieve $7 \%$ of lipids, was defined taking into account the fat content obtained for the sources, ACRU: 7.47 $\%$ and ACRU treated: $14.70 \%$.

\section{Blood Analysis}

Glucose, total cholesterol and triglycerides, were determined by enzymatic methods using commercial kits.

All applicable international, national, and/or institutional guidelines for the care and use of animals were followed.

\section{Statistical Analysis}

Results are expressed as mean \pm standard deviation. Statistical differences were tested by the Student's $t$-test and ANOVA. Probabilities of 0.05 or less indicate significant difference (Snedecor and Cochran 1991).

\section{Results and Discussion}

The present work studied the effect of thermal treatment on the proximal chemical composition, elemental profile, antioxidant activity and biological value of the protein of a new Amaranthus cruentus L. variety seed flour, as well as the effect of its intake on some serum parameters.

Table 2 shows the proximal chemical composition, where the protein and lipid contents stand out, reaching values of 19.59 and $7.47 \mathrm{~g} / 100 \mathrm{~g}$, respectively, in ACRU. These values are higher than the informed by Bressani (2003) for proteins, and similar in the case of lipids. In ACRU treated, these results increase significantly in $17 \%$ and $50 \%$, respectively.
Regarding the elemental profile (Table 3), in general, the results obtained are increased in the treated sample, in accordance with the ash value informed. Among the main elements of nutritional interest (expressed in $\mu \mathrm{g} / \mathrm{g}$ of flour), it is highlighted the presence of $\mathrm{Ca}: 1592.15$ and 1974.25, Fe: 85.50 and 106.02, Na: 49.00 and 60.76, S: 7.71 and 9.56, and $\mathrm{Cu}$ : 6.49 and 8.03, for ACRU and ACRU treated, respectively, and a high content of $\mathrm{P}$ and $\mathrm{K}$ in both samples. The concentrations of these minerals is similar to the informed by Nascimento et al. (2014), and do not exceed the maximum tolerable levels. The $\mathrm{Ca}$ contribution of the studied flours could participate in the prevention of osteopenia and osteoporosis, which frequently affect coeliacs patients. No presence of toxic mineral elements, such as As and $\mathrm{Cd}$, is detected, while $\mathrm{Pb}$ and Cr slightly exceed the limit allowed by the FAO/WHO (2015) $(0.20 \mathrm{ppm}$ for $\mathrm{Pb}$ and $0.10 \mathrm{ppm}$ for $\mathrm{Cr}$ ).

Form the investigated anti-nutrients (Table 4), it is observed that nitrates increase significantly $(35 \%)$ in the treated sample; however, both values obtained (206.44 and 316.27 $\mathrm{mg} / 100 \mathrm{~g}$ ) are within the acceptable range. The Joint FAO/WHO Expert Committee has determined as Acceptable Daily Intake (ADI) of nitrates a value of $0-3.7 \mathrm{mg} / \mathrm{kg}$ of body weight (FAO/WHO 2002). Regarding the hemagglutinin activity, it is observed that they are concordant with the obtained by Escudero et al. (2004) for grain amaranths, and do not affect health. No presence of saponins is observed. A significant decrease is observed in the antitryptsin activity in 
ACRU treated, due to that these proteases inhibitors are thermolabile. The results obtained for ACRU and ACRU treated, 3.49 and $2.86 \mathrm{TIU} / \mathrm{mg}$, respectively, are similar to the reported for seeds of other amaranth species (Bressani, 1994). The values informed are close to the levels considered as safe (5 TIU/mg of sample). The concentration of oxalic acid in ACRU is $156.00 \mathrm{mg} / 100 \mathrm{~g}$, decreasing in $8 \%$ for ACRU treated, value that is similar to regular consumption cereals. Considering that the Hendek Ertop and Bektaş (2015) recommends patients with kidney stones an oxalate-restricted diet with values below 40 to $50 \mathrm{mg}$ per day, the daily intake of ACRU should be reduced. The phytic acid content was of 0.36 and $1.38 \mathrm{mg} \mathrm{P} / 100 \mathrm{~g}$ in ACRU and ACRU treated, respectively, lower than the informed for amaranth $(82 \mathrm{mg} / 100$ g) by Ferreira and Arêas (2010).

The amaranth grain contributes with natural antioxidants that play an import role in the inhibition of free radicals, preventing oxidative deterioration. The values obtained for

total phenols were 16.23-39.23 mg gallic acid / $100 \mathrm{~g}$ for ACRU and ACRU treated, respectively (Table 5), similar to the informed by Repo de Carrasco and Encina Zelada (2008) for six varieties of Amaranthus caudatus. The significant increase of phenols in the treated sample would be a consequence of the release of these compounds by the action of the thermal treatment. The evaluated antioxidant activity does not present significant differences between both samples, with varying ranges for \% Inhibition for DPPH: 88.84-89.51; NO: 65.73-72.21; and $\beta$-carotene: 25.03-26.65. It is noted the capacity of free radical scavenging given by the DPPH inhibition percentage. It is interesting the high percentage obtained for the NO Test, considering that NO produced in excess interacts with oxygen forming nitrites that transform into harmful peroxides; Czerwinski et al. (2004) inform lower values that vary between 23.00 and $25.10 \%$ NO inhibition. The bleaching percentage of $\beta$-carotene, as a measurement of the lipid peroxidation inhibition, is relatively low and in agreement with the informed for Amaranthus hypochondriacus by the same author.

Regarding the evaluation of the biological quality of the studied samples (Table 6), it is observed that the diets consumption does no present significant differences between the experimental diets, and neither with respect to casein taken as reference. However, the weight gain decreases significantly $(87 \%)$ with respect to the animal protein; these results can be attributed to the characteristics that distinguish a vegetable protein. The feces weight presents a significant increase with respect to casein, probably due to the fiber present in the vegetable diet. In the biological tests, NPU presents lower values for the studied samples with respect to casein, being lower for the treated sample. The tD does not show significant differences between the experimental samples, so it can be inferred that it is not affected by the thermal treatment. The BV results are lower for the treated sample, indicating that this treatment decreases the protein quality, and consequently, its utilization for protein synthesis.

Table 2. Chemical composition of the new variety in the dry weight of Acru-G10/13 II and Acru-G10/13 II treated seed flours

\begin{tabular}{lll}
\hline $\begin{array}{l}\text { Determination } \\
\text { (g/100g) }\end{array}$ & ACRU & ACRU treated \\
\hline Moisture & $7.28 \pm 0.15^{\mathrm{a}}$ & $1.13 \pm 0,01^{\mathrm{b}}$ \\
Ash & $4.46 \pm 0,16^{\mathrm{a}}$ & $5.53 \pm 0,04^{\mathrm{b}}$ \\
Protein $(\mathrm{N}$ x 6.25) & $19.59 \pm 0,13^{\mathrm{a}}$ & $23.54 \pm 0,15^{\mathrm{b}}$ \\
Total lipids & $7.47 \pm 0.18^{\mathrm{a}}$ & $14.70 \pm 0.12^{\mathrm{b}}$ \\
Carbohydrates & $61.20 \pm 0.43^{\mathrm{a}}$ & $55.10 \pm 0.30^{\mathrm{b}}$ \\
Crude fiber & $5.86 \pm 0.14^{\mathrm{a}}$ & $5.91 \pm 0.06^{\mathrm{a}}$ \\
\hline
\end{tabular}

Values are mean \pm standard deviation of three measurements. Different letters indicate significant differences $(\mathrm{p}<0.05)$.

${ }^{*}$ Carbohydrates are determined by the following calculation:

Carbohydrates $=100-(\%$ Ash $)-(\%$ Total Fat $)-(\%$ Moisture $)-(\%$ Protein $)$ 
Table 3. Concentration of 21 elements analyzed in the dry weight of Acru-G10/13 II and Acru-G10/13 II treated seed flours $(\mu \mathrm{g} / \mathrm{g})$

\begin{tabular}{lll}
\hline Element & ACRU & ACRU treated \\
\hline $\mathbf{A s}$ & ND & ND \\
$\mathbf{C a}$ & $1592.15 \pm 75^{\mathrm{a}}$ & $1974.25 \pm 83^{\mathrm{b}}$ \\
$\mathbf{C d}$ & $\mathrm{ND}$ & $\mathrm{ND}$ \\
$\mathbf{C o}$ & $0.11 \pm 0.005^{\mathrm{a}}$ & $0.14 \pm 0.008^{\mathrm{b}}$ \\
$\mathbf{C u}$ & $6.49 \pm 0.03^{\mathrm{a}}$ & $8.03 \pm 0.06^{\mathrm{b}}$ \\
$\mathbf{C r}$ & $0.16 \pm 0.007^{\mathrm{a}}$ & $0.18 \pm 0.009^{\mathrm{b}}$ \\
$\mathbf{F e}$ & $85.50 \pm 5.70^{\mathrm{a}}$ & $106.02 \pm 7.50^{\mathrm{b}}$ \\
$\mathbf{K}^{*}$ & $>10$ & $>10$ \\
$\mathbf{H g}$ & $\mathrm{ND}$ & $\mathrm{ND}$ \\
$\mathbf{L i}$ & $0.98 \pm 0.06^{\mathrm{a}}$ & $1.21 \pm 0.04^{\mathrm{b}}$ \\
$\mathbf{M g *}$ & $>10$ & $>10$ \\
$\mathbf{M n}$ & $37.47 \pm 2.40^{\mathrm{a}}$ & $46.46 \pm 3.35^{\mathrm{b}}$ \\
$\mathbf{M o}$ & $0.53 \pm 0.06^{\mathrm{a}}$ & $0.64 \pm 0,07^{\mathrm{a}}$ \\
$\mathbf{N a}$ & $49.00 \pm 2.78^{\mathrm{a}}$ & $60.76 \pm 4.25^{\mathrm{b}}$ \\
$\mathbf{N i}$ & $0.37 \pm 0.001^{\mathrm{a}}$ & $0.46 \pm 0.002^{\mathrm{b}}$ \\
$\mathbf{P *}$ & $>10000$ & $>10000$ \\
$\mathbf{S}$ & $7.71 \pm 0.50^{\mathrm{a}}$ & $9.56 \pm 0.45^{\mathrm{b}}$ \\
$\mathbf{I}$ & $\mathrm{ND}$ & $\mathrm{ND}$ \\
$\mathbf{P b}$ & $1.15 \pm 0.009^{\mathrm{a}}$ & $1.43 \pm 0.01^{\mathrm{b}}$ \\
$\mathbf{S e}$ & $\mathrm{ND}$ & ND \\
$\mathbf{Z n}$ & $32.33 \pm 1.87^{\mathrm{a}}$ & $40.09 \pm 2.25^{\mathrm{b}}$ \\
\hline
\end{tabular}

Values are mean \pm standard deviation of three measurements. Different letters indicate significant differences $(\mathrm{p}<0.05)$.

*Exceeds the upper quantification limit. ND: not detected

Table 4. Anti-nutrient factors in the dry weight of Acru-G10/13 II y Acru-G10/13 II treated seed flour

\begin{tabular}{|c|c|c|}
\hline Anti-nutrient factors & ACRU & ACRU treated \\
\hline Nitrates $(\mathrm{mg} / \mathbf{1 0 0} \mathrm{g})$ & $206.44 \pm 17.67^{\mathrm{a}}$ & $316.27 \pm 32.19^{b}$ \\
\hline Hemagglutinin activity & $1 / 64$ & $1 / 16$ \\
\hline Hemolytic activity & ND & ND \\
\hline Foam index & $<100$ & $<100$ \\
\hline Antitrypsin activity (TIU/mg sample) ${ }^{\#}$ & $3.49 \pm 0.30^{\mathrm{a}}$ & $2.86 \pm 0.10^{\mathrm{b}}$ \\
\hline Oxalic acid (mg/100 g) & $156.00 \pm 4.04^{\mathrm{a}}$ & $144.32 \pm 3.90^{\mathrm{b}}$ \\
\hline Phytic acid (mg P/100 g) & $0.36 \pm 0.01^{\mathrm{a}}$ & $1.38 \pm 0.09^{\mathrm{b}}$ \\
\hline
\end{tabular}

Values are mean \pm standard deviation of three measurements. Different letters indicate significant differences $(\mathrm{p}<0.05)$

ND: Not detected.

*1000/a; $\mathrm{a}=\mathrm{mL}$ of filtrate in the tube that reached, when no tube exhibited $1 \mathrm{~cm}$ of foam, foam index $<100$.

"Trypsin inhibited units per mg of flour. 
Table 5. Total phenols content and antioxidant activity in the dry weight of Acru-G10/13 II and Acru-G10/13 II treated seed flours

\begin{tabular}{lll}
\hline & ACRU & ACRU treated \\
\hline Total phenols (mg gallic acid /100 g) & $16.23 \pm 0.10^{\mathrm{a}}$ & $39.23 \pm 0.99^{\mathrm{b}}$ \\
DPPH inhibition (\%) & $89.51 \pm 1,66^{\mathrm{a}}$ & $88.84 \pm 2.14^{\mathrm{a}}$ \\
NO inhibition (\%) & $65.73 \pm 1.63^{\mathrm{a}}$ & $72.21 \pm 2.58^{\mathrm{a}}$ \\
$\boldsymbol{\beta}$-carotene inhibition (\%) & $25.03 \pm 1.89^{\mathrm{a}}$ & $26.65 \pm 0.97^{\mathrm{a}}$ \\
\hline
\end{tabular}

Values are mean \pm standard deviation of three measurements.

Different letters indicate significant differences $(\mathrm{p}<0.05)$

Table 6. Biological quality from seed flour of Acru-G10/13 II y Acru-G10/13 II treated

\begin{tabular}{llll}
\hline & Casein & ACRU & ACRU treated \\
\hline Intake (g) & $74.08 \pm 10.94^{\mathrm{a}}$ & $60.70 \pm 7.17^{\mathrm{a}}$ & $66.90 \pm 7.37^{\mathrm{a}}$ \\
Weight gain (g) & $17.70 \pm 2.38^{\mathrm{a}}$ & $2.75 \pm 0.75^{\mathrm{b}}$ & $1.83 \pm 0.15^{\mathrm{b}}$ \\
Feces weight (g) & $5.51 \pm 0.46^{\mathrm{a}}$ & $8.44 \pm 1.96^{\mathrm{b}}$ & $7.44 \pm 0.85^{\mathrm{b}}$ \\
NPU & $63.21 \pm 6.85^{\mathrm{a}}$ & $45.39 \pm 5.23^{\mathrm{b}}$ & $33.99 \pm 3.22^{\mathrm{c}}$ \\
tD & $96.23 \pm 2.19^{\mathrm{a}}$ & $83.90 \pm 4.32^{\mathrm{b}}$ & $86.33 \pm 4.60^{\mathrm{b}}$ \\
BV & $65.69 \pm 5.69^{\mathrm{a}}$ & $54.10 \pm 4.53^{\mathrm{a}}$ & $39.37 \pm 3.20^{\mathrm{b}}$ \\
\hline
\end{tabular}

The results are expressed as mean \pm standard deviation

Different letters indicate significant differences $(\mathrm{p}<0.05)$

NPU: Net protein utilization, tD: true digestibility, BV: Biological value

Table 7. Effect of ACRU-G10/13 II and ACRU-G10/13 II treated seed flours on biochemical variables

\begin{tabular}{llll}
\hline $\begin{array}{l}\text { Biochemical variables } \\
(\mathbf{m g} / \mathbf{d L})\end{array}$ & Casein & ACRU & ACRU treated \\
\hline Glucose & $53.25 \pm 11.70^{\mathrm{a}}$ & $62.40 \pm 8.88^{\mathrm{a}}$ & $77.66 \pm 21.08^{\mathrm{a}}$ \\
Total Cholesterol & $53.40 \pm 11.33^{\mathrm{a}}$ & $39.60 \pm 12.34^{\mathrm{a}}$ & $38.00 \pm 5.05^{\mathrm{a}}$ \\
Triglycerides & $131.40 \pm 33.28^{\mathrm{a}}$ & $89.40 \pm 6.58^{\mathrm{b}}$ & $70.20 \pm 18.40^{\mathrm{b}}$ \\
\hline
\end{tabular}

The results are expressed as mean \pm standard deviation

Different letters indicate significant differences $(p<0.05)$

The evaluated serum parameters (Table 7) indicate that the triglycerides level decreases significantly in the experimental samples, with a tendency in the decrease of total cholesterol with respect to casein, values similar to the reported by Escudero et al. (2006). This could be explained by the presence of dietary fiber and the prevalence of unsaturated fatty acids in the vegetal diet.

\section{Conclusions}

The obtained results allow to conclude that the thermal treatment used $\left(90^{\circ} \mathrm{C}\right.$ for $\left.1 \mathrm{~h}\right)$ affects the content of nutrients. It improves the protein and lipid contents, however, the biological study indicates that the thermal treatment decreases the protein quality when its biological value and net protein utilization are affected. The content of minerals of nutritional importance increases in the treated sample, highlighting the presence of $\mathrm{Ca}, \mathrm{Fe}$ and $\mathrm{P}$, without observing toxic elements.
The antinutrients studied are within ranges that do not affect health, suggesting the potential consumption of this variety without apparent toxicity risk. The concentration of total phenols indicates that the amaranth grain contributes with antioxidants that play an important role in free-radical scavenging, preventing oxidative deterioration; the sample subjected to thermal treatment increases its phenol content. On the other hand, a beneficial effect of the amaranths grains is observed by producing a hypotriglyceridemic effect. However, and despite that, in general, the thermal treatment improves some of the evaluated parameters, it decreases the protein quality. This is an aspect that should be contemplated for performing future studies, subjecting that sample to different types of thermal treatments that do not affect the biological quality of the protein. This also becomes a challenge for the food technology, with the goal of optimizing the nutritional quality of this amaranth. 


\section{Compliance with Ethical Standard}

Conflict of interests: The authors declare that for this article they have no actual, potential or perceived the conflict of interests.

Acknowledgements: The authors thank Dr. Eloy Salinas for his contribution in the serum determinations.

\section{References}

Aguilar, E.G., Cantarelli, M.A., Marchevsky, E.J., Escudero, N.L., Camiña, J.M. (2011). Multielemental analysis and classification of amaranth seeds according to their botanical origin. Journal of Agricultural and Food Chemistry, 59, 9059-9064.

https://doi.org/10.1021/jf202610t

AOAC (2012). Moisture, Gravimetric Method AOAC $\mathrm{N}^{\circ}$ 920.151; Ash, Complete Ignition Method AOAC N 940.26; Protein, Kjeldahl Method AOAC N 920.152; Lipid, Soxhlet Method AOAC $\mathrm{N}^{\circ}$ 950.48; Crude fiber AOAC $\mathrm{N}^{\circ}$ 930.10. Official methods of analysis of the AOAC International, 19th ed. Gaithersburg, MD, USA.

AOAC (1995). Calcium Oxalate Precipitation Method. AOAC $\mathrm{N}^{\circ}$ 42.1.18. Official Methods of Analysis. Official methods of analysis of the AOAC international, 17th ed. Arlington, Virginia.

Barba de la Rosa, A.P., Fomsgaard, I.S., Laursen, B., Mortensen, A.G., Olvera-Martínez, L., Silva-Sánchez, C., Mendoza-Herrera, A., González-Castañeda, J., De LeónRodríguez, A. (2009). Amaranth (Amaranthus hypochondriacus) as an alternative crop for sustainable food production: phenolic acids and flavonoids with potential impact on its nutraceutical quality. Journal of Cereal Science, 49, 117-121. https://doi.org/10.1016/j.jcs.2008.07.012

Bressani, R. (1994). Composition and nutritional properties of amaranth. In: Paredes-Lopez O (ed) Amaranth Biology, Chemistry and Technology (p. 185-205). CRC Press, Boca Raton FL.

https://doi.org/10.1201/9781351069601-10

Bressani, R. (2003). Amaranth. In: Caballero B (ed) Encyclopedia of Food Sciences and Nutrition, 2nd ed. (p. 166173). Academic Press, Oxford.

https://doi.org/10.1016/B0-12-227055-X/00036-5
Burits, M., Bucar, F. (2000). Antioxidant activity of Nigella sativa essential oil. Phytotherapy Research: PTR, 14,323-328.

https://doi.org/10.1002/1099-

1573(200008)14:5<323::AID-PTR621>3.0.CO;2-Q

Cataldo, D., Haroon, M., Schrader, L., Youngs, V. (1975). Rapid colorimetric determination of nitrate in plant tissue by nitration of salicylic acid. Communications in Soil Science and Plant Analysis, 6, 71-80.

https://doi.org/10.1080/00103627509366547

Czerwiński, J., Bartnikowska, E., Leontowicz, H., Lange, E., Leontowicz, M., Katrich, E., Trakhtenberg, S., Gorinstein, S. (2004). Oat (Avena sativa L.) and amaranth (Amaranthus hypochondriacus) meals positively affect plasma lipid profile in rats fed cholesterol-containing diets. The Journal of Nutritional Biochemistry, 15(10), 622629.

https://doi.org/10.1016/j.jnutbio.2004.06.002

Das Gupta, B.R., Boroff, D.A. (1968). Separation of toxin and hemagglutinin from crystalline type A by anion exchange chromatography and determination of their dimension by gel filtration. The Journal of Biological Chemistry, 243, 1065-1072.

Do Prado, V.C., Antunes, P.L., Sgarbieri, V.C. (1980). Antinutrients occurrence and some physicochemical properties of the protein fractions of five Brazilian soybean varieties. Archivos Latinoamericanos de Nutrición, 30, 551563.

Dodok, A.A., Modhir, V., Buchtová, V., Halásová, G., Poláček, I. (1997). Importance and utilization of amaranth in food industry. Part 2. Composition of amino acids and fatty acids. Nahrung, 41, 108-110.

https://doi.org/10.1002/food.19970410211

Duarte-Correa, A., Jokl, L., Carlsson, R. (1986). Chemical constituents, in vitro protein digestibility and presence of antinutritional substance in amaranth grains. Archivos Latinoamericanos de Nutrición, 36, 319-326.

Emmons, C.L., Peterson, D.M., Paul, G.L. (1999). Antioxidant capacity of oat (Avena sativa L.) extracts. 2. In vitro 
antioxidant activity and contents of phenolic and tocol antioxidants. Journal of Agricultural and Food Chemistry, 47, 4894-4898.

https://doi.org/10.1021/jf990530i

Escudero, N.L., Arellano, M.L., Luco, J.M., Gimenez, M.S., Mucciarelli, S.I. (2004). Comparison of the chemical composition and nutritional value of Amaranth cruentus flour and its protein concentrate. Plant Foods for Human Nutrition, 59 (1), 15-21.

https://doi.org/10.1007/s11130-004-0033-3

Escudero, N.L., Zirulnik, F., Gomez, N.N., Mucciarelli, S.I., Gimenez, M.S. (2006). Influence of a protein concentrates from Amaranthus cruentus seeds on lipid metabolism. Experimental Biology and Medicine / Society for Experimental Biology and Medicine, 231(1), 50-59.

https://doi.org/10.1177/153537020623100106

FAO/WHO Food and Agriculture Organization of the United Nations/World Health Organization (2015). Change by General standard for contaminants and toxins in food and feed (Codex stan 193-1995). http://www.fao.org/input/download/standards/17/CXS 193e_2015.pdf (accessed 09.11.2019)

FAO/WHO Food and Agriculture Organization of the United Nations/World Health Organization (2002). Evaluations of the Joint FAO/WHO Expert Committee on Food Additives (JECFA). http://apps.who.int/food-additives-contaminants-jecfa-database/chemical.aspx?chemID $=709 \#$ (accessed 09.11.2019)

Ferreira, T.M., Arêas, J.A.G. (2010). Biodisponibilidade do cálcio do grão de amaranto antes e após extrusão Ciencia e Tecnologia de Alimentos. Ciência e Tecnologia de Alimentos, 30(2), 532-538.

https://doi.org/10.1590/S0101-20612010000200037

Giami, S.Y., Adindu, M.N., Hart, A.D., Denenu, E.O. (2001). Effect of heat processing on in vitro protein digestibility and some chemical properties of African breadfruit (Treculia africana decne) seeds. Plant Foods for Human Nutrition, 56, 117-126.

https://doi.org/10.1023/A:1011181412808
Hendek Ertop, M., Bektaş, M. (2018). Enhancement of bioavailable micronutrients and reduction of antinutrients in foods with some processes. Food and Health, 4(3), 159-165. https://doi.org/10.3153/FH18016

Kakade, M., Rackis, J., McGhee, J., Puski, G. (1974). Determination of trypsin inhibitor activity of soy products: A collaborative analysis of an improved procedure. Cereal Chemistry, 51, 376-382.

Koleva, I.I., van Beek, T.A., Linssen, J.P., de Groot, A., Evstatieva, L.N. (2002). Screening of plant extracts for antioxidant activity: a comparative study on three testing methods. Phytochemical Analysis: PCA, 13, 8-17.

https://doi.org/10.1002/pca.611

Marcocci, L., Packer, L., Droy-Lefaix, M.T., Sekaki, A., Gardès-Albert, M. (1994). Antioxidant action of Ginkgo biloba extract EGb 761. Methods in Enzymology, 234, 462-475. https://doi.org/10.1016/0076-6879(94)34117-6

Miller, D.S., Bender, A.E. (1955). The determination of the net utilization of proteins by a shortened method. The British Journal of Nutrition, 9, 382-388.

https://doi.org/10.1079/BJN19550055

Nascimento, A.C., Mota, C., Coelho, I., Gueifão, S., Santos, M., Matos, A.S., Gimenez, A., Lobo, M., Samman, N., Castanheira, I. (2014). Characterization of nutrient profile of quinoa (Chenopodium quinoa), amaranth (Amaranthus caudatus), and purple corn (Zea mays L.) consumed in the North of Argentina: Proximates, minerals and trace elements. Food Chemistry, 148, 420-426.

https://doi.org/10.1016/j.foodchem.2013.09.155

Pellet, P.L., Young, V.R. (1980). Nutritional evaluation of protein foods. Tokyo: The United Nations University. (Publication $\mathrm{N}^{\circ}$ WHTR-3/UNUP-129) Japan.

Reeves, P.G., Nielsen, F.H., Fahey, G.C. Jr (1993). AIN-93 Purified diets for laboratory rodents: final report of the American Institute of Nutrition Ad Hoc writing committee on the reformulation of the AIN-76A rodent diet. The Journal of Nutrition, 123, 1939-1951.

https://doi.org/10.1093/jn/123.11.1939 
Repo de Carrasco, R., Encina-Zelada, C.R. (2008). Determinación de la capacidad antioxidante y compuestos fenólicos de cereales andinos: quinua (Chenopodium quinoa), kañiwa (Chenopodium pallidicaule) y kiwicha (Amaranthus caudatus). Revista de la Sociedad Química del Perú, 74(2), 85-99.

Rucci, A.O., Bertoni, M.H. (1974). Determinación de ácido fítico en subproductos de semillas de girasol. Anales de la Asociación Química Argentina, 62, 365-368.

Saija, A., Tomaino, A., Lo Cascio, R., Trombetta, D., Proteggente, A., De Pasquale, A., Uccella, N., Bonina, F. (1999). Ferulic and caffeic acids as potential protective agents against photooxidative skin damage. Journal of the Science of Food and Agriculture, 79, 476-480.

https://doi.org/10.1002/(SICI)1097-

$\underline{0010(19990301) 79: 3<476:: A I D-J S F A 270>3.0 . C O ; 2-L}$

Salcedo-Chávez, B., Osuna-Castro, J.A., Guevara-Lara, F., Domínguez-Domínguez, J., Paredes-López, O. (2002). Optimization of the isoelectric precipitation method to obtain protein isolates from Amaranth (Amaranthus cruentus) seeds. Journal of Agricultural and Food Chemistry, 50, 6515-6520. https://doi.org/10.1021/jf020522t
Snedecor, G.W., Cochran, W.G. (1991). Statistical Methods, 8th ed., Wiley. ISBN: $0813815614,9780813815619$.

Sun, M., Um, T., Sun, H., Zhang, M. (2014). Digestibility and structural properties of thermal and high hydrostatic pressure treated sweet potato (Ipomoea batatas L.) protein. Plant Foods for Human Nutrition, 69, 270-275.

https://doi.org/10.1007/s11130-014-0426-9

Tosi, E.A., Ré, E., Lucero, H., Masciarelli, R. (2001). Dietary fiber obtained from amaranth (Amaranthus cruentus) grain by differencial milling. Food Chemistry, 73(4), 441443.

https://doi.org/10.1016/S0308-8146(00)00326-5

Vinson, J.A., Proch, J., Bose, P. (2001). Determination of the quantity and quality of polyphenol antioxidants in foods and beverages. Methods in Enzymology, 335, 103-114. https://doi.org/10.1016/S0076-6879(01)35235-7

WHO/PHARM/92559 (1992) Quality Control Methods for Medicinal Plant Materials (811,36-37). World Health Organization, Geneva 27, Switzerland. 